\title{
A multi-criteria decision-making model for evaluating priorities for foreign direct investment
}

\author{
Korhan K. Gokmenoglu ${ }^{1, *}$ and Shahram Alaghemand ${ }^{1}$ \\ ${ }^{1}$ Banking and Financing Department, \\ Eastern Mediterranean University, \\ Famagusta, North Cyprus \\ via Mersin 10, Turkey \\ E-mail: 〈korhan.gokmenoglu@emu.edu.tr, sh.alaghemand@gmail.com〉
}

\begin{abstract}
The objective of this study is to evaluate the relative priority of nine developed countries as a home country for foreign direct investment (FDI) from the vantage point of the United States during three time periods: pre-crisis (2004-2006), crisis (2007-2009), and post-crisis (2010-2012). Our study suggests a methodology based on a combination of the analytic hierarchy process (AHP), the technique for order preference by similarity to ideal solution (TOPSIS), and the multi-period multi-attribute decision-making (MP-MADM) technique. To investigate our research question, we selected fifteen robust FDI determinants from recent studies. The results for all three time periods show that productivity, market potential, market size, GDP growth and development have the highest priority in the decision-making process. On the other hand, we found that the 2007 global financial crisis significantly affected each variable in the decision-making process. During the crisis, two variables in particular - corruption and GDP growth - significantly increased in importance. These findings have farreaching policy implications and can assist policymakers and investors in their strategic decision-making process.
\end{abstract}

Key words: FDI, AHP, TOPSIS, MP-MA decision making

Received: March 15, 2015; accepted: October 14, 2015; available online: October 31, 2015

DOI: $10.17535 /$ crorr.2015.0037

\section{Introduction}

Capital flows from one country to another in a variety of ways, one of which is foreign direct investment (FDI). The Organisation for Economic Co-operation and Development [24] defines FDI as "a category of investment that reflects the objective of establishing a lasting interest ${ }^{\dagger}$ by a resident enterprise in one economy (direct investor) in an enterprise (direct investment enterprise) that is

\footnotetext{
* Corresponding author.

† The pivotal characteristics of FDI are a high degree of control and influence on the management of enterprises and a long-term relationship between the direct investment enterprise and the investor.
} 
a resident in an economy other than that of the direct investor". Generally, during the FDI process, investors in one country (the home country) obtain ownership of assets in another country (the host country) to control the main activities of a firm including management, production, and distribution [21]. The literature claims that FDI has important effects on the transferal of technology and other skills, domestic productivity [9], capital accumulation, acquisition, innovative capacity, and economic growth [21].

Given the importance of FDI, its determinants have been extensively described in the literature. Researchers have focused on several factors as determinants of FDI inflow-outflow, including bilateral distance [23, 22, 5], trade costs in the host and home countries, gross domestic product (GDP), GDP growth rate [35], market size of the host country relative to other countries [11, $2,7,10]$, productivity [28], differences in factor endowments, exchange rate volatility [12], financial system development, economic policy activity [17], financial risk [28], host and source corporate tax rates [27], the existence of regional trade agreements [3], country-pair specific impacts, such as language [25], border and colonial history, legal protection, and the quality of institutions $[6]$.

Empirical works employ several regressors to identify FDI determinants. However, many of these studies do not take into account the possibility that both the set of decision-making criteria and their importance for decision-makers may change over time. It is known that financial crises may cause such structural changes. Both the volume and direction of the FDI flow were significantly affected especially in developed countries following the 2007 global financial crisis. Therefore, consideration of the priority of FDI with respect to different spans of time for these countries could obtain comprehensive results regarding the determinants of FDI and the decision-making process for FDI inflow-outflow across countries. To this end, our study was based on three periods, namely pre-crisis (2004-2006), crisis (2007-2009), and post-crisis (20102012).

In addition, another weakness of the earlier studies was selection bias in the data sets. It is well worth mentioning that missing data jeopardizes the validity of FDI theories as well. Recently, [10] carried out a study to construct robust FDI determinants. They employed Heckit Bayesian Model Averaging (HBMA), which is concerned with model uncertainties regarding the validity of competing FDI theories and selection bias. Using this methodology, which results in robust FDI determinants, they found that more than $50 \%$ of the suggested FDI determinants were not robust. We constructed our model based on fifteen robust FDI determinants, namely distance, market size, colony, common language, development, GDP growth, market potential, productivity, tax, LAIA, APEC, dollar, corruption risk, internal conflict risk, and religious tension risk as suggested in the study conducted by [10]. 
We selected as the home country the United States (US), which has the largest share of FDI outflow. For the target countries (or host countries), we selected nine developed countries: Australia, Canada, Germany, Ireland, Japan, Luxembourg, the Netherlands, Switzerland, and the United Kingdom, which together receive the largest share of US FDI outflow.

This study aims to contribute to the literature by considering the latest robust FDI determinants as decision-making criteria and investigating the investment destination priorities in the three different time periods of pre-crisis, crisis, and post-crisis by developing a model based on a combination of AHP, TOPSIS and MP-MADM techniques. AHP was implemented to obtain FDI determinant weights in the decision process, and the TOPSIS method was employed to prioritize the alternatives. MP-MADM techniques were employed to aggregate the relevant data in each of the three periods. Investigating the FDI host countries' rankings in different time spans not only reinforces the validity of the designed model, but also results in a more comprehensive model. Using subjective methods helped obtain more realistic results and increased the flexibility of the model; however, inputs based on various experts' judgments resulted in different weight distributions among the decision criteria and consequently changed the output of the entire model.

Using a methodology that generates optimum output in the prioritizing of countries to invest in will create greater added value for multinational enterprise companies and assist policymakers and investors in their strategic decisionmaking. Furthermore, the output of the decision about FDI priority is used as an input in many other decision-making processes, such as policymaking, the establishment of foreign relations with other countries, and the terms of different trade agreements.

The rest of this paper is organized as follows. The next section presents a literature review. Section 3 provides a discussion of the methodology used in evaluating the determinants of FDI. Section 4 reports and discusses the empirical results obtained. Section 5 is a discussion and provides a final concluding section.

\section{Literature review}

Decision making is a process of selecting the best among different alternatives. Wagner [32] mentioned that "Unquestionably most, if not all, decision making is part of an unending history of action. Earlier choices have affected the present, current decisions will influence the future, and so on". As a decision-making problem becomes complicated, obtaining the best solution will become more complex. Decision-making is one of the most important problems of all sciences. Finding the best option from several feasible alternatives is naturally one of the main areas of interest areas in economics, which as a science deals with the 
problem of scarce resources. In economics and finance literature, decisionmaking models are used to investigate several topics including evaluation of economic development differences [33], objective and subjective ratings [8], allocation of asset and mutual funds [31], portfolio selection [20], and energy management [16].

Finding an optimum location to invest in is suited to multi-attribute decision-making methods (MADM). MADM involves making a priority decision in finite alternative environments that are described by multiple, usually conflicting, attributes [14]. This methodology selects optimum alternatives by considering a high degree of satisfaction among all decision attributes [34]. In this regard, Beim \& Le'vesque [4] comment that the MADM method can be considered superior based on some of its features such as sensitivity analysis, ability to express DM preference, that it is easily replicable by entrepreneurs. They employ fifteen FDI criteria in four major categories (i.e. cultural, economic, legal, political perspectives) to rank countries (fourteen) for new business ventures. The preferences used to weight each determinant vary for the five different entrepreneurs acting as decision makers.

The analytic hierarchy process (AHP) is another method used to investigate a decision-making process for FDI. AHP, developed by Saaty [29], is based on pairwise comparison. In this regards, the importance of each attribute is compared one by one relative to the others. This process will be carried out by expert individual judgments and are scored using a specific ratio scale. This methodology solves and analyses problems similar to those addressed by the human brains. AHP enables a decision maker to determine the contrary and simultaneous impacts of numerous complicated circumstances. Levary \& Wan [18] developed AHP to rank the FDI entry mode possibilities of individual firms. In this approach, AHP is used to overcome the uncertainty of FDI including future expectations of foreign direct investment and pairwise comparisons of a decision-maker's judgment, which are entailed in AHP. In their explanatory example on US multinational FDI in China, they defined four alternatives including: whole ownership, majority- and minority-owned joint ventures and no entry as an entry mode, and subsequently ranking them according to their decision criteria (uncertainties) and five different scenarios. Grčić \& Babić [13] constructed AHP evaluation to rank particular transition countries (fifteen countries in Europe and the Baltic states) for FDI. In this study, several variables were employed as determinants of FDI. The results have revealed that the Central Eastern European and Baltic States (except Lithuania) at the top of the scale, and the Southeastern European countries are at the bottom of the scale. Abid \& Bahloul [1] suggest an approach that combines AHP and a goalprogramming model for evaluating the priority of selected MENA countries as a destination for FPI, from the perspective of investors from G7 countries for the period 2001-2005. They have concluded that amending bilateral trade and institutional quality for a MENA country in addition to reducing foreign 
investment limitation information costs are pivotal solutions in attract more foreign portfolio investments.

Hwang \& Yoon [14] constructed an approach, called the technique for order preference by similarity to ideal solution (TOPSIS). The approach in this methodology is quite unique but easy to comprehend. The best alternative from this method is selected based on the assumption; it should have the shortest Euclidean distance ${ }^{\ddagger}$ from the ideal solution and the farthest distance ${ }^{\S}$ from the negative-ideal solution. The best alternative is obtained by the highest relative closeness measure. ${ }^{* *}$ Lin \& Tsai [19] provide a model for ranking 15 regions and subsequently chose a location for FDI in Chinese recently developed hospitals based on MCDM. Karimi, et al. [15] examine the location decision for FDI by applying TOPSIS methodology in ASEAN countries from 2000 to 2005. In order to provide the ranking, they defined ten indicators as FDI determinants inflows and subsequently concluded that among the considered countries, Singapore was most attractive country for investment. Radfar \& Ebrahimi [26] identify and prioritize various FDI methods for transfer of technology in the ship building industry using the Fuzzy TOPSIS method. They have shown that of various foreign investment methods, the joint venture and the subsidiary company have the highest and lowest priorities, respectively.

\section{Data and methodology}

\subsection{Data description}

Data used in this study are annual figures for the period of 2004-2012. We have divided this period into three sub-periods depending on different economic situations and defined them as a pre-crisis, crisis, post-crisis span of time. This model has been constructed to evaluate US FDI outflow priority in nine top FDI partnerships, namely, Australia, Canada, Germany, Ireland, Japan, Luxembourg, Netherland, Switzerland, and United Kingdom.

Our study employs fifteen robust FDI criteria based on the study of Eicher et al. [10] which constructs the determinants by considering two important constraints in an FDI database, i.e. uncertainty and selection bias. Table 1 references the data source for each determinant. Table 2 illustrates the bilateral and host country's FDI determinants that have been employed in this study, and also reveals the characteristic and effect of each determinant on FDI flows.

\footnotetext{
$\mathrm{d}_{\mathrm{i}}^{+}=\sqrt{\left[\sum\left(\mathrm{v}_{\mathrm{ij}}-\mathrm{v}_{\mathrm{j}}^{+}\right)\right]^{2}}, \mathrm{v}_{\mathrm{j}}^{+}=($the best value for jth criteria $)$

${ }^{\S} \mathrm{d}_{\mathrm{i}}^{-}=\sqrt{\left[\sum\left(\mathrm{v}_{\mathrm{ij}}-\mathrm{v}_{\mathrm{j}}^{-}\right)\right]^{2}}, \mathrm{v}_{\mathrm{j}}^{-}=($the worst value for jth criteria $)$

${ }^{* *}$ relative closeness measure: $\frac{\mathrm{d}_{\mathrm{i}}^{-}}{\left(\mathrm{d}_{\mathrm{i}}^{+}+\mathrm{d}_{\mathrm{i}}^{-}\right)}$
} 


\begin{tabular}{|c|c|}
\hline Criteria & Date Source \\
\hline (1) DISTANCE & CEPII \\
\hline (2) MRKT_SIZE & The World Bank \\
\hline (3) $\mathrm{COLONY}$ & CEPII \\
\hline (4) COM_LANG & CEPII \\
\hline (5) DEVELOPMENT & OEDC \\
\hline (6) GDP_GROWTH & OEDC \\
\hline (7) MRKT_POTENTIAL & CEPII \\
\hline (8) PRODUCTIVITY & The World Bank \\
\hline (9) TAX & http://taxfoundation.org/article/oecd-corporate-income-tax-rates-1981-2012 \\
\hline (10) LAIA & http://www.aladi.org/ \\
\hline (11) APEC & http://www.apec.org/ \\
\hline (12) DOLLAR & http://wn.com/currency_union \\
\hline (13) CORRUPT & International Country Risk Guid \\
\hline (14) INTERN_CONFLICT & International Country Risk Guid \\
\hline (15) RELIGIOUS_TENSION & International Country Risk Guid \\
\hline
\end{tabular}

Table 1: Data source

\begin{tabular}{|c|c|c|c|}
\hline Category & Criteria & Description & $\begin{array}{l}\text { Effect on } \\
\text { FDI Flow }\end{array}$ \\
\hline \multirow[t]{2}{*}{ Gravity } & (1) DISTANCE & Natural log of bilateral distance & - \\
\hline & (2) MRKT SIZE & Host country natural log of real GDP & + \\
\hline \multirow[t]{2}{*}{ Geography/history } & (3) COLONY & Share colonial relationship (If yes, $=2$ then, $=1$ ) & + \\
\hline & (4) COM LANG & Share common language (If yes, =2 then, $=1$ ) & + \\
\hline Factor endowment & (5) DEVELOPMENT & Host country natural log of real GDP per capita & + \\
\hline \multirow[t]{3}{*}{ Growth and productivity } & (6) GDP GROWTH & Host country GDP growth rate & + \\
\hline & (7) MRKT POTENTIAL & Sum of host country's distance-weighted GDP to all other countries & - \\
\hline & (8) PRODUCTIVITY & Host country productivity (real GDP per worker) & + \\
\hline Fiscal/monetary policy & (9) $\mathrm{TAX}$ & Host country corporate effective tax rate & - \\
\hline \multirow[t]{3}{*}{ RTAs/CUs/investment } & (10) LAIA & Latin American Integration Agreement (If yes, $=2$ then, $=1$ ) & - \\
\hline & (11) APEC & The Asia-Pacific Economic Community (If yes, =2 then, =1) & + \\
\hline & (12) DOLLAR & Dollar Currency Unions (If yes, =2 then, $=1$ ) & + \\
\hline Economic risk & (13) CORRUPT* & Host country corruption & + \\
\hline \multirow[t]{2}{*}{ Political risk } & (14) INTERN CONFLICT* $*$ & Host country internal conflict & + \\
\hline & (15) RELIGIOUS TENSION* & Host country religion in politics & + \\
\hline
\end{tabular}

* In the everycase the lower the riskpoint (value), the higher the risk, and the higher the risk point total the lower the risk

Table 2: FDI criteria

\subsection{Methodology}

In this study, four types of analyses are employed. First, the AHP method is used to evaluate the FDI determinant weights in three periods (pre-crisis, crisis, post-crisis). Second, a vector normalization approach is used to normalize all 
data relating to each set of FDI determinants for each country. Third, a dynamic weighted averaging operator is employed to aggregate multi-period data in three different spans of time (pre-crisis, crisis, post-crisis). Lastly, the TOPSIS method is applied to prioritize alternative countries based on defined FDI determinants.

\subsubsection{Weighting FDI criteria}

The AHP method was employed to determine the FDI criteria weight. The weights were calculated for each period separately based on expert judgment. Based on AHP, the following steps had to be considered:

Step 1: Construction of a pairwise comparison matrix from criteria and each of these judgments is assigned a number on a scale based on Saaty's [30] rating scale Table A-1. The general pairwise comparison matrix can be constructed as follows (all arrays of the matrix are arranged by considering $a_{i j}=\frac{1}{a_{j i}}$ )

\begin{tabular}{|c|c|c|c|c|}
\hline Criteria & $C_{1}$ & $C_{2} \cdots$ & $C_{j} \cdots$ & $C_{n}$ \\
\hline$C_{1}$ & 1 & $a_{12} \cdots$ & $a_{1 j} \cdots$ & $a_{1 n}$ \\
\hline $\begin{array}{c}C_{2} \\
\vdots\end{array}$ & $\begin{array}{c}1 / a_{12} \\
\vdots\end{array}$ & $\begin{array}{c}1 \cdots \\
\vdots\end{array}$ & $\begin{array}{c}a_{2 j} \cdots \\
\vdots\end{array}$ & $\begin{array}{c}a_{2 n} \\
\vdots\end{array}$ \\
\hline $\begin{array}{c}C_{i} \\
\vdots\end{array}$ & $\begin{array}{c}1 / a_{1 j} \\
\vdots\end{array}$ & $\begin{array}{c}1 / a_{2 j} \\
\vdots\end{array}$ & $\begin{array}{c}1 \cdots \\
\vdots\end{array}$ & $\begin{array}{c}a_{\text {in }} \\
\vdots\end{array}$ \\
\hline$C_{n}$ & $\begin{array}{c}1 / a_{1 n} \\
1 / a_{2 n}\end{array}$ & $\begin{array}{c}1 / a_{\text {in }} \\
\text {. }\end{array}$ & 1 \\
\hline
\end{tabular}

Figure 1: General pairwise comparison matrix

Step 2: Normalization of pairwise comparison matrix:

$$
\mathrm{n}_{\mathrm{ij}}=\frac{\mathrm{a}_{\mathrm{ij}}}{\sum_{\mathrm{i}=1}^{\mathrm{n}} \mathrm{a}_{\mathrm{ij}}} \text {, where } \mathrm{i}, \mathrm{j}=1,2, \ldots, n
$$

Step 3: Calculation of the arithmetic average of each row of normalized pairwise comparison matrix:

$$
\mathrm{W}_{\mathrm{i}}=\frac{\sum_{j=1}^{\mathrm{n}} \mathrm{n}_{i j}}{\mathrm{n}}, \text { where } \mathrm{i}=1,2, \ldots, n
$$

At the end of this step, criteria weights are calculated and following steps are followed to test the consistency of judgments. 
Step 4: Calculation of the weighted sum vector:

$$
W S V=\text { pairwise comparison matrix } \times \text { matrix of } w_{j}(\text { step } 3)
$$

Step 5: Calculation of the consistency vector:

$$
C V=W S V \div W j(\text { each array one by one })
$$

Step 6: Calculation of the maximum Eigen value of the pairwise comparison matrix $\left(\lambda_{\max }\right)$

$$
\lambda_{\max }=\frac{\sum C V}{\mathrm{n}}
$$

Step 7: Calculation of the inconsistency index (II) and Consistency Ratio CR

$$
\begin{gathered}
I I=\frac{\lambda_{\max }-\mathrm{n}}{n-1} \\
C R=\frac{I I}{I R I}
\end{gathered}
$$

To calculate $C R$ for provided judgments, the Table A-2 derived from Saaty [30] was used. The upper row of the table provides the order of the random matrix, whereas the lower row introduces random judgments of the corresponding consistency index. According to Saaty [30], a consistency ratio greater than 0.1, implies that judgments can sometimes be accepted when the consistency limit for $C R \mathrm{~s}$ is higher than 0.1 (but not much greater). AHP can be performed for the group rather than individual judgments. Therefore, the geometric average will be aggregated.

\subsubsection{Normalization}

After preparing each determinant weight, the next step is normalization of the decision matrix, allowing comparison of attributes. The vector normalization method was employed in this study to attain the harmonize decision matrix.

$$
r_{i j}=\frac{x_{i j}}{\sqrt{\sum_{i=1}^{m} x_{i j}^{2}}}, i=1, \ldots, m ; j=1, \ldots, n
$$

$r_{i j}$, is normalized value of alternative $i$, with regards to $j^{\text {th }}$ criteria.

\subsubsection{Aggregation of multi-period decision making}

In general, most of the previous studies related to multi-attribute decisionmaking problems have used the same time period information; however, this paper will consider the information at different periods. Therefore, time dependent aggregation operators or a dynamic weighted averaging (DWA) 
factor were prepared to aggregate information, which is the most important step in aggregation of MADM information. Accordingly, different DWA operators such as the arithmetic, geometric series and normal distribution can be employed. Moreover, the multi-period MADM can be used when the periods are expressed in interval numbers. The study consists of three different economic periods, pre-crisis, crisis, post-crisis. Each period is composed of 3 years. To aggregate the relevant data into the three mentioned periods, the following steps are to be considered.

Step 1: Normalization of a decision matrix for each year. Considering $R\left(t_{k}\right)$ as a normalized decision matrix and $r_{i j}\left(t_{k}\right)$ as an attribute value for the year $\mathrm{t}_{\mathrm{k}}(\mathrm{k}$ $=1,2, \ldots, \mathrm{y})$.

$R\left(t_{k}\right)=\left(r_{i j}\left(t_{k}\right)\right)_{m \times n} \quad \mathrm{k}=1,2, \ldots, \mathrm{y}$

Step 2: Calculation of a weighted averaging operator.

$$
V_{i}=\sum_{k=1}^{y} \lambda^{p}\left(t_{k}\right) v_{i}\left(t_{k}\right), i=1,2, \ldots, \text { and } P=1,2,3
$$

for the purpose of aggregating the respective year of data in each three periods. In our study, each period consists of three successive years, so that $\mathrm{k}$ spans from one to three and $\mathrm{P}=1, \mathrm{P}=2$ and $\mathrm{P}=3$ denote the pre-crisis, crisis and post crisis periods. Then, the weighted averaging operator $\left(v_{i}\right)$ is utilized by :

$$
v_{i}\left(t_{k}\right)=\sum_{j=1}^{n} w_{j}\left(t_{k}\right) r_{i j}\left(t_{k}\right), i=1,2, \ldots, m
$$

And, weight vector is $\lambda^{p}(t)=\left\{\lambda^{p}\left(t_{1}\right), \lambda^{p}\left(t_{2}\right), \ldots, \lambda^{p}\left(t_{y}\right)\right\}^{T}$, where $\lambda^{p}\left(t_{y}\right) \geq 0, k=$ $1,2, \ldots, y, \sum_{k=1}^{y} \lambda^{p}\left(t_{y}\right)=1$.

Note that $\lambda^{p}(\mathrm{t})$ can be given by a decision maker or can be drawn from different methods such as those based on the arithmetic series, geometric series and normal distribution.

\subsubsection{TOPSIS}

The TOPSIS method was constructed on the concept of the alternative with the shortest distance and farther distance from the positive and negative ideal solutions is considered the best-chosen alternative. TOPSIS was considered due to its ability to be combined with other decision-making methods such as AHP [33]. Six major steps are taken to achieve the optimum ranking of alternatives: 
Step 1: Quantification and normalization of the decision matrix.

Step 2: Calculation of a weighed normalized decision matrix: Multiplication of a normalized decision matrix $(\mathrm{R})$ with respect to a diagonal matrix of criteria weights $\left(W_{n \times n}\right)$

$$
V=R \times W_{n \times n}
$$

Step 3: To define the ideal positive $\left(\mathrm{V}_{\mathrm{j}}^{+}\right)$and negative $\left(\mathrm{V}_{\mathrm{j}}^{-}\right)$solutions:

$\left(\mathrm{V}_{\mathrm{j}}^{+}\right)$: [Vector of each criterion's best value in $\mathrm{V}$ ]. The best value for positive and negative criteria will be the maximum and minimum amount, respectively.

$\left(\mathrm{V}_{\mathrm{j}}^{-}\right)$: [Vector of each criterion's worst value in $\mathrm{V}$ ]. The worst value for positive and negative criteria will be the minimum and maximum amount, respectively.

Step 4: To find each alternative distance from the positive $\left(\mathrm{V}_{\mathrm{j}}^{+}\right)$and negative $\left(\mathrm{V}_{\mathrm{j}}^{-}\right)$ideal alternatives:

$$
d_{i}^{+}=\sqrt{\left[\sum\left(v_{i j}-v_{j}^{+}\right)\right]^{2}}, i=1,2 \ldots, \mathrm{m}
$$

where $\mathrm{v}_{\mathrm{j}}^{+}$is the best value for each attribute irrespective of the alternative.

$$
d_{i}^{-}=\sqrt{\left[\sum\left(v_{i j}-v_{j}^{-}\right)\right]^{2}}, i=1,2 \ldots, \mathrm{m}
$$

where $v_{j}^{-}$is the worst value for each attribute.

Step 5: To calculate the integrated evaluation index CL (relative closeness measure)

$$
C L_{i}^{*}=\frac{d_{i}^{-}}{\left(d_{i}^{+}+d_{i}^{-}\right)}
$$

Step 6: Rank alternatives: the highest value of CL, the better alternative.

Note that TOPSIS is carried out for each three aggregated periods, separately.

\section{Empirical results}

\subsection{Criteria weighting}

The AHP method was employed to calculate the weights of each criterion in this study. The weighting process was carried out for each period separately as indicated in the previous sections. To complete the pairwise comparison matrix, we considered the expert judgments of four foreign investment experts. Three matrixes were constructed to show the pre-crisis, crisis, and post-crisis periods. The following table illustrates the aggregated FDI criteria weights with respect to the AHP method. 


\begin{tabular}{|c|c|c|c|c|c|c|c|c|c|c|c|c|c|c|c|}
\hline & DIST ANCE & $\begin{array}{l}\text { MRKT } \\
\text { SIZE }\end{array}$ & COLONY & COM LANG & DEVELOPMENT & GDP GROWTH & $\begin{array}{l}\text { MRKT } \\
\text { POTENTIAL }\end{array}$ & PRODUCTIVTT & TAX & LAIA & APEC & DOLLAR & CORRUPTION & $\begin{array}{l}\text { INTERN } \\
\text { CONFLICT }\end{array}$ & $\begin{array}{l}\text { RELIGIOUS } \\
\text { TENSION }\end{array}$ \\
\hline Pre Crisis: & $5.21 \%$ & $12.42 \%$ & $1.62 \%$ & $1.62 \%$ & $9.22 \%$ & $11.42 \%$ & $14.00 \%$ & $14.17 \%$ & $6.65 \%$ & $2.70 \%$ & $2.70 \%$ & $2.72 \%$ & $4.67 \%$ & $5.17 \%$ & $5.72 \%$ \\
\hline Crisis: & $5.33 \%$ & $12.69 \%$ & $1.39 \%$ & $1.39 \%$ & $8.24 \%$ & $15.12 \%$ & $12.64 \%$ & $11.75 \%$ & $6.41 \%$ & $2.08 \%$ & $2.08 \%$ & $2.08 \%$ & $6.88 \%$ & $5.93 \%$ & $6.00 \%$ \\
\hline Post Crisis: & $: 7.57 \%$ & $13.27 \%$ & $1.31 \%$ & $1.31 \%$ & $12.54 \%$ & $11.79 \%$ & $10.97 \%$ & $10.24 \%$ & $6.50 \%$ & $2.42 \%$ & $2.42 \%$ & $2.46 \%$ & $5.76 \%$ & $5.88 \%$ & $5.54 \%$ \\
\hline
\end{tabular}

Table 3: Criteria weights

To reach the desired degree of consistency in the expert judgments, the consistency ratio was calculated for each of the three matrixes using steps 4 to 7 as illustrated in the previous section. The following table shows the consistency ratio for each averaged pairwise matrix (using the geometric average), consisting of four individual matrixes for each pre-crisis, crisis, and post-crisis period.

\begin{tabular}{|c|c|c|c|}
\hline & Pre Crisis & Crisis & Post Crisis \\
\hline$\lambda \max$ & 16.973 & 17.158 & 16.712 \\
\hline $\mathrm{CR}$ & 0.089 & 0.097 & 0.077 \\
\hline
\end{tabular}

*Note: Saaty's CI table: $n=15$ and the relevant $C I=1.59$

Table 4: Consistency ratios

The CR calculations for the matrices demonstrate that the required degree of consistency was achieved. AHP results reveal that, during the pre-crisis period, productivity in the host countries gained the highest weight, $14.17 \%$ compared to the other factors. However, in the crisis period, the productivity weight declined to $11.75 \%$ (fourth level), while GDP growth received the greatest priority in comparison to other FDI determinants by $15.12 \%$. The other significant development during the crisis period was an increase in the importance of corruption. Previous studies claimed that a larger market size in host countries affects positively FDI outflow. According to our study, in the post-crisis period, a weight of $12.69 \%$ was allocated to the market size criteria, making it the most important determinant. Results for criteria weighting are reported in Figure 2.

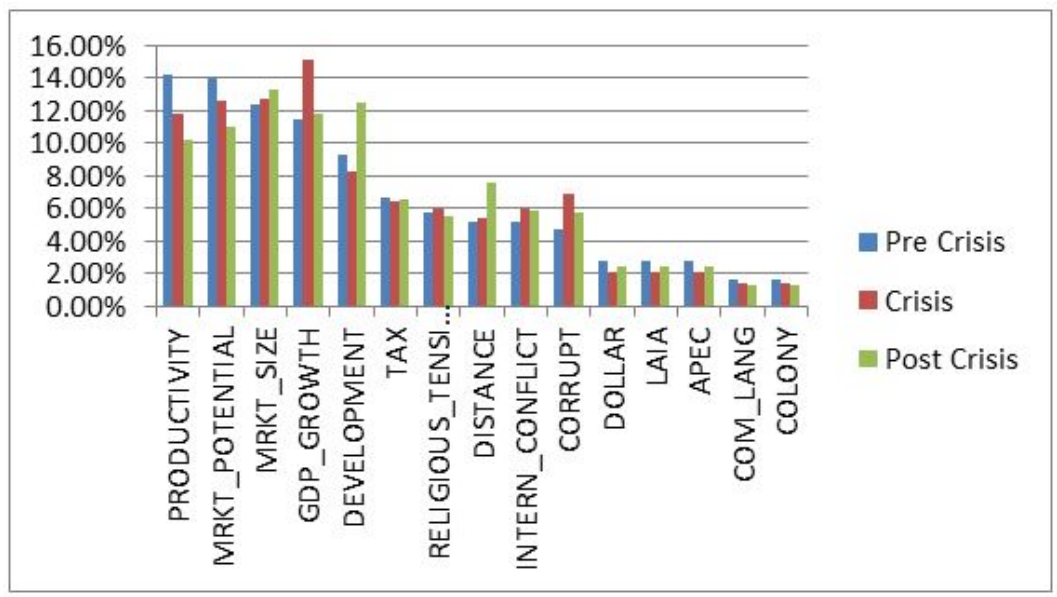

Figure 2: FDI criteria weight rankings 


\subsection{Normalization}

The next step after gathering data for all FDI determinants was normalization of the decision matrixes (all nine matrixes separately) based on equation (8). Therefore, all the decision matrix arrays were in the same dimension, so that the comparison among them becomes applicable.

\subsection{TOPSIS results and analysis}

After calculating the normalized decision matrices, the next step was the construction of a weighted normalized decision matrix based on equation (11). This step was carried out for each year employing the criteria weight matrix. In order to aggregate yearly decision matrixes in our defined economic periods, a weighted vector was selected. In this study uniform distribution was employed; thus in each period, all years have the same effect on the defined periods. Therefore, with regards to equation (10), it was assumed for each period (precrisis, crisis, and post-crisis) that $\lambda^{p}\left(t_{1}\right)=\lambda^{p}\left(t_{2}\right)=\lambda^{p}\left(t_{3}\right)=1 / 3$.

The next step in the TOPSIS methodology was to determine the positive and negative ideal solutions. In this regard, for criteria that identify a positive condition, the positive ideal solution is the maximum value, and the negative ideal solution is the minimum value. On the other hand, for criteria that identify a negative condition, the positive and negative ideal solutions are the minimum and maximum values, respectively. For instance, in our study, distance was characterized as a negative criterion given that as bilateral distance increases, FDI flow decreases.

In the next step, the distance of each alternative from the positive and negative ideal solutions was calculated using equations (12) and (13). Then, relative closeness indices were computed using equation (14).

The last step was to rank (in descending order) the relative closeness indexes, the highest values in the CL index, and the better alternatives for investment. In the pre-crisis period, Japan with a CL of 0.5767 was ranked number one, followed by Canada $(\mathrm{CL}=0.4602)$ and Germany $(\mathrm{CL}=0.4339)$. Tables 5 through to 10 present the results for positive and negative ideal solutions including the distance and relative closeness of the ideal solution for each of the three periods. 


\begin{tabular}{|c|c|c|c|c|c|c|c|c|c|c|c|c|c|c|}
\hline & DISTANCE MRKT SIZE & COLONY & COM LANG & $\begin{array}{l}\text { DEVEL } \\
\mathrm{T}\end{array}$ & $\begin{array}{l}\text { N GDP } \\
\text { GROWTH }\end{array}$ & $\begin{array}{l}\text { MRKT } \\
\text { POTENTIAL }\end{array}$ & $\begin{array}{l}\text { PRODUCTIV } \\
\text { ITY }\end{array}$ & $\operatorname{Tax}$ & LAIA & $\mathrm{APEC}$ & DOLAR & CORRUPT & $\begin{array}{l}\text { INTERN } \\
\text { CONFLICT } \\
\end{array}$ & $\begin{array}{l}\text { RELGIOUS } \\
\text { TENSION }\end{array}$ \\
\hline${ }^{i+}$ & 0.0012 & 0.0093 & 0.0071 & 0.0531 & 0.0583 & 0.0074 & 0.0932 & 0.0089 & 0.0078 & 0.0127 & 0.0099 & 0.0139 & 0.0206 & 0.0224 \\
\hline i- & 0.0007 & 0.0047 & 0.0035 & 0.0237 & 0.0201 & 0.0741 & 0.0357 & 0.0230 & 0.0078 & 0.0064 & 0.0049 & 0.0096 & 0.0126 & 0.0119 \\
\hline
\end{tabular}

Table 5: Positive and negative ideal solutions (Pre-crisis)

The results for positive and negative ideal solutions for each criterion during the pre-crisis period are presented in Table 5 using step 3 of TOPSIS methodology (defining as the best and worst value of vector of each criterion).

\begin{tabular}{|c|c|c|c|c|c|}
\hline \multicolumn{2}{|c|}{$\begin{array}{l}\text { Distance from } \\
\text { Positive Ideal }\end{array}$} & \multicolumn{2}{|c|}{$\begin{array}{l}\text { Distance from } \\
\text { Negative Ideal }\end{array}$} & Alternatives & CL Index \\
\hline d1+ & 0.0902 & d1- & 0.0615 & \multicolumn{2}{|c|}{ United Kingdom 0.4053} \\
\hline $\mathrm{d} 2+$ & 0.1234 & d2- & 0.0291 & Netherland & 0.1908 \\
\hline d3+ & 0.0928 & d3- & 0.0791 & Canada & 0.4602 \\
\hline $\mathrm{d} 4+$ & 0.1137 & d4- & 0.0787 & Luxembourg & 0.4089 \\
\hline d5+ & 0.1066 & d5- & 0.0618 & Ireland & 0.3668 \\
\hline d6+ + & 0.1156 & d6- & 0.0385 & Switzerland & 0.2497 \\
\hline d7+ & 0.0912 & d7- & 0.0699 & Germany & 0.4339 \\
\hline d8+ + & 0.1062 & d8- & 0.0724 & Australia & 0.4055 \\
\hline d9+ & 0.0805 & d9- & 0.1096 & Japan & 0.5767 \\
\hline
\end{tabular}

Table 6: Distance and relative closeness to the ideal solution (Pre-crisis)

In regards to Table 6 , the distance from positive and negative ideal solution for each nine alternatives was calculated and relative closeness index computed for the pre-crisis period.

\begin{tabular}{|c|c|c|c|c|c|c|c|c|c|c|c|c|c|c|c|}
\hline & DISTANCE & MRKT SIZE & COLONY & COM LANG & $\begin{array}{l}\text { DEVELOPM } \\
\text { ENT } \\
\end{array}$ & $\begin{array}{l}\text { GIDP } \\
\text { GROWTH } \\
\end{array}$ & $\begin{array}{l}\text { MRRKI } \\
\text { POTENIIAL } \\
\end{array}$ & $\begin{array}{l}\text { PRODUCTIV } \\
\text { ITY }\end{array}$ & TAX & LAIA & APEC & DOLAR & CORRUPT & $\begin{array}{l}\text { INIERN } \\
\text { CONELICT } \\
\end{array}$ & $\begin{array}{l}\text { RELIGIOUS } \\
\text { TENSION } \\
\end{array}$ \\
\hline it & 0.0012 & 0.0918 & 0.0080 & 0.0061 & 0.0477 & 0.0566 & 0.0071 & 0.0772 & 0.0086 & 0.0060 & 0.0098 & 0.0072 & 0.0208 & 0.0238 & 0.0242 \\
\hline j- & 0.0355 & 0.0008 & 0.0040 & 0.0030 & 0.0206 & -0.0235 & 0.0665 & 0.0292 & 0.0233 & 0.0060 & 0.0049 & 0.0036 & 0.0125 & 0.0134 & 0.0113 \\
\hline
\end{tabular}

Table 7: Positive and negative ideal solutions (crisis period)

Table 7 shows the calculated ideal solutions based on acquired data over the crisis period. 


\begin{tabular}{|c|c|c|c|c|c|}
\hline \multicolumn{2}{|c|}{$\begin{array}{l}\text { Distance from } \\
\text { Positive Ideal }\end{array}$} & \multicolumn{2}{|c|}{$\begin{array}{l}\text { Distance from } \\
\text { Negative Ideal }\end{array}$} & Alternatives & CL Index \\
\hline $\mathrm{d} 1+$ & 0.1025 & d1- & 0.0624 & United Kingdom & 0.3782 \\
\hline $\mathrm{d} 2+$ & 0.1176 & d2- & 0.0510 & Netherland & 0.3026 \\
\hline d3+ & 0.0986 & d3- & 0.0788 & Canada & 0.4442 \\
\hline $\mathrm{d} 4+$ & 0.1219 & d4- & 0.0691 & Luxembourg & 0.3618 \\
\hline d5+ & 0.1278 & d5- & 0.0463 & Ireland & 0.2659 \\
\hline d6+ & 0.1103 & d6- & 0.0622 & Switzerland & 0.3609 \\
\hline d7+ & 0.0908 & d7- & 0.0761 & Germany & 0.4562 \\
\hline d8+ & 0.0982 & d8- & 0.1025 & Australia & 0.5107 \\
\hline d9+ & 0.1020 & d9- & 0.1060 & Japan & 0.5098 \\
\hline
\end{tabular}

Table 8: Distance and relative closeness to the ideal solution (crisis period)

Table 8 shows the distances and relative closeness indexes for the crisis period.

\begin{tabular}{|c|c|c|c|c|c|c|c|c|c|c|c|c|c|c|c|}
\hline & DISTANCE & MRKT SIZE & COLONY & COM LANG & $\begin{array}{l}\text { DEVELOPM } \\
\text { ENT } \\
\end{array}$ & $\begin{array}{l}\text { GIPP } \\
\text { GROWTH } \\
\end{array}$ & $\begin{array}{l}\text { MRKT } \\
\text { POTENTIAL }\end{array}$ & $\begin{array}{l}\text { PRODUCTIV } \\
\text { L ITY } \\
\end{array}$ & TAX & LAIA & APEC & DOLLAR & CORRUPT & $\begin{array}{l}\text { INTERN } \\
\text { CONELLCT } \\
\end{array}$ & $\begin{array}{l}\text { RELIGIOUS } \\
\text { TENSION }\end{array}$ \\
\hline i+ & 0.0017 & 0.0953 & 0.0076 & 0.0057 & 0.0705 & 0.0549 & 0.0066 & 0.0646 & 0.0088 & 0.0070 & 0.0114 & 0.0086 & 0.0169 & 0.0233 & 0.0222 \\
\hline i- & 0.0504 & 0.0008 & 0.0038 & 0.0029 & 0.0323 & 0.0060 & 0.0575 & 0.0264 & 0.0215 & 0.0070 & 0.0057 & 0.0043 & 0.0122 & 0.0169 & 0.0148 \\
\hline
\end{tabular}

Table 9: Positive and negative ideal solutions (post-crisis period)

Table 9 demonstrates the ideal solutions as in Table 5 and 7; however, in this table the ideal solutions were achieved based on post-crisis figures.

\begin{tabular}{|llllll|}
\hline $\begin{array}{l}\text { Distance from } \\
\text { Positive Ideal }\end{array}$ & \multicolumn{3}{l}{$\begin{array}{l}\text { Distance from } \\
\text { Negative Ideal }\end{array}$} & Alternatives & CL Index \\
\hline $\mathrm{d} 1+$ & 0.0860 & $\mathrm{~d} 1-$ & 0.0645 & United Kingdom & 0.4285 \\
$\mathrm{~d} 2+$ & 0.1187 & $\mathrm{~d} 2-$ & 0.0367 & Netherland & 0.2362 \\
$\mathrm{~d} 3+$ & 0.0828 & $\mathrm{~d} 3-$ & 0.0862 & Canada & 0.5102 \\
$\mathrm{~d} 4+$ & 0.1125 & $\mathrm{~d} 4-$ & 0.0678 & Luxembourg & 0.3760 \\
$\mathrm{~d} 5+$ & 0.1130 & $\mathrm{~d} 5-$ & 0.0479 & Ireland & 0.2978 \\
$\mathrm{~d} 6+$ & 0.1080 & $\mathrm{~d} 6-$ & 0.0485 & Switzerland & 0.3099 \\
$\mathrm{~d} 7+$ & 0.0696 & $\mathrm{~d} 7-$ & 0.0860 & Germany & 0.5529 \\
$\mathrm{~d} 8+$ & 0.1039 & $\mathrm{~d} 8-$ & 0.0738 & Australia & 0.4155 \\
$\mathrm{~d} 9+$ & 0.0689 & $\mathrm{~d}+$ & 0.1088 & Japan & 0.6121 \\
\hline
\end{tabular}

Table 10: Distance and relative closeness to the ideal solution (post-crisis period)

Table 10 depicts the post crisis relative closeness index to the ideal solution for the alternative host countries.

\subsection{Ranking and comparison}

The results obtained by calculating the relative closeness for each of the nine alternative over the three periods were sorted from largest to smallest and as shown in Figure 3. 
A multi-criteria decision-making model for evaluating priorities

for foreign direct investment

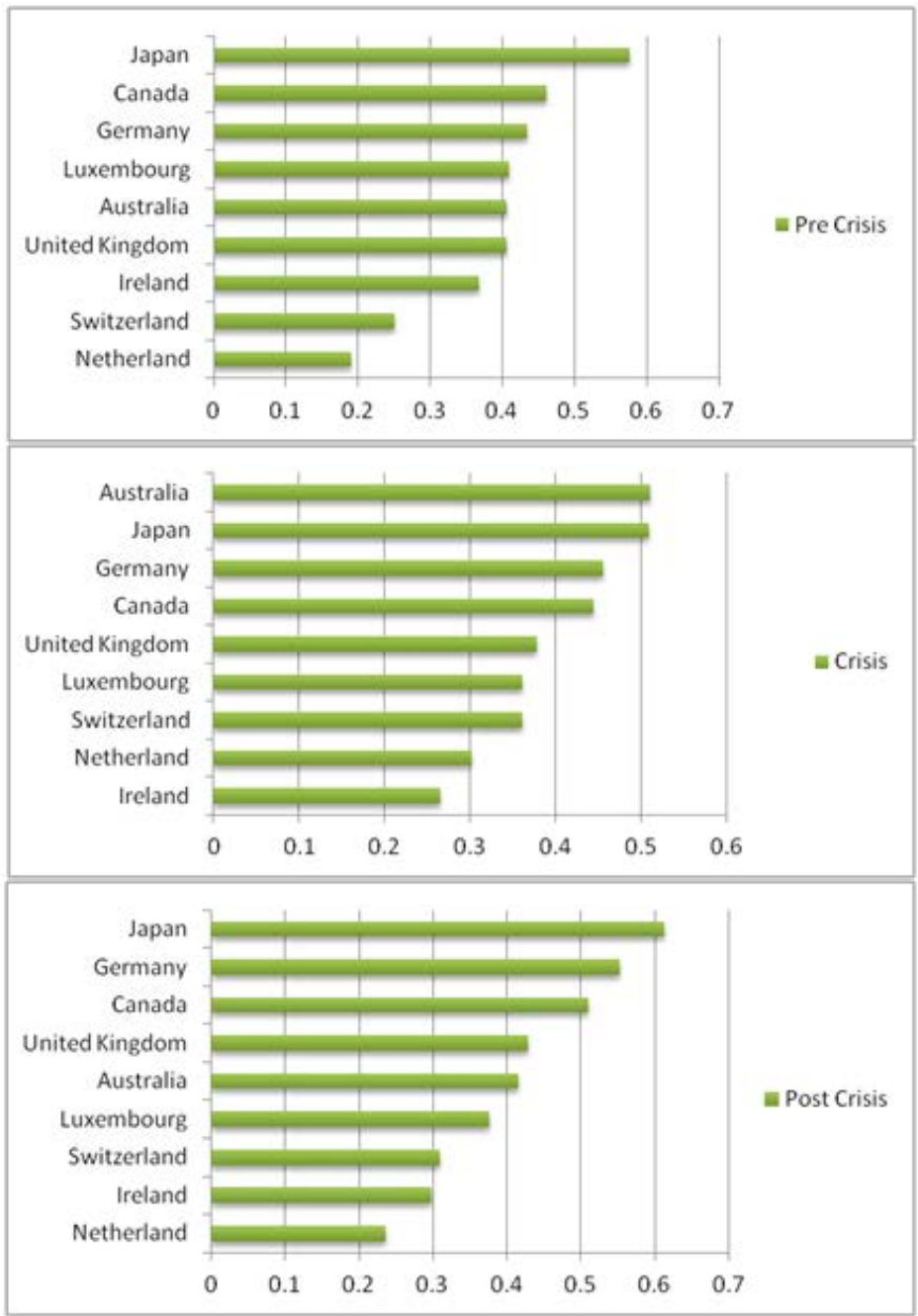

Figure 3: Alternative rankings for pre-crisis, crisis and post-crisis periods

According to our designed output model, the US's first priority in increasing FDI outflow in the pre-crisis and post-crisis periods is Japan. Economic growth in Japan in 2004 was the highest recorded since 1996. Furthermore, Japan is considered one of the largest world markets, and has a stable, developed business environment. Additionally, Japan's forceful relationship with developing countries in Asia makes the country a good business opportunity for foreign investors. Japan is considered a center of innovation in the world, connecting Asia with the rest of the world. Therefore, the favourable conditions associated with Japan's market size, market potential, and productivity resulted in its surpassing the other eight alternatives. 
During the crisis period, Japan fell to second place while Australia rose to the top with a closeness index of 0.5107 . Table A-3, which shows the aggregated weighted decision matrix during pre-crisis, reveals that the proximity to the ideal point of some of Japan's more important, or highly weighted, FDI determinants, such as a market size of 0.09145 and a market potential of 0.01456, have made Japan more attractive for US investors. Meanwhile, Australia by obtaining a weight of 0.05664 for GDP growth and 0.00710 for market potential (the two most important FDI criteria according to Table A-4 criteria weights) forced Japan in the number-two slot during the crisis period. In the third period, however, the attractiveness of Australia declined sharply. The decline of its GDP growth during the post-crisis period was one of the main reasons Australia slipped down to fifth place during this period.

The high ranking for Canada can be explained due to its close distance to the US, its high market potential as one of the richest countries in the world in terms of its natural resource base, its high quality human resources, and its flexible labour market. The pivotal factor in drawing the attention of foreign investors to Germany is its stable and powerful economy. Focusing on the weighted matrix, market size and market potential significantly enhances Germany's attractiveness to foreign investors.

Luxembourg is an ideal alternative compared to other countries in terms of its productivity $(0.07725)$ and the risk of corruption (0.020803), religious tension (0.022247), and internal conflict (0.024221). However, its market size, market potential, and GDP growth $(0.00081,0.06649$, and 0.00337 respectively) are farther from the ideal solutions when compared with other alternatives during the crisis period.

Ireland, Switzerland, and the Netherlands occupied the last three slots during all three periods. Since the mid-1990s, Ireland has been improving its economic conditions. However, when hit by the financial crisis and negative GDP growth (-0.01954) during the crisis period, it fell from seventh place to last. Switzerland's GDP growth weight of 0.02737 ranked it as the closest of all the countries to the ideal solution. Australia was next at 0.05663. However, when considering other determinants, it ranked seventh in market size and market potential during the crisis. In the crisis period, the Netherlands was considered the ideal solution in regard to corruption risk and internal conflict risk, but the weights of its other FDI determinants were not as satisfactory as those of the other countries in our data set.

\section{Discussion}

This study attempted to design a model to evaluate the attractiveness of host countries for FDI. The findings reveal that productivity, market potential, market size, GDP growth, and development were the most important determinants of FDI in all three time periods investigated. However, language 
and colonial relationship, factors that represent geographic and historical variables, are the least important variables. Furthermore, the importance of international agreements and unions is very low in comparison to growth and factor endowment categories. This finding implies that the size of a country's economy and its growth potential are pivotal factors for FDI inflow - a conclusion that should provide guidance for policymakers in countries that are competing for FDI inflow.

On the other hand, the effect of time must be taken into account, because it is clear that the importance of almost all the variables changes over time. In particular, the importance of GDP growth and risk of corruption increased considerably during the 2007 financial crisis. Following the crisis, many developed countries experienced a negative GDP growth rate, which made investors very sensitive to fluctuations in this variable. So the countries that had positive GDP growth were favoured by the decision makers. Since corruption has been one of the most significant causes of economic crises, it was no surprise that it had a higher criteria weight ranking in our findings. The conclusion is that, during financial turbulence, countries able to maintain a positive GDP growth rate and remain free of corruption have the best chance of attracting FDI.

Any change in criteria weight ranking also affects the position of the countries in the alternative ranking table. Almost all the countries were ranked differently in the pre-crisis, crisis, and post-crisis periods. The importance of development, GDP growth, market size, and market potential during the postcrisis period affected significantly the priority of the target countries' FDI. The aggregated data for this period has revealed that Japan, Germany, and Canada each played a vital role as a host country for the US to increase its investments. When it comes to market size, Japan still accounts for more than $55 \%$ of the entire Asian retail market and is the second largest market in the world after the US. Germany has been able to recover quickly after the crisis in comparison to the other countries. The crisis had affected Germany's GDP growth, which became negative, but after the crisis passed, the numbers were positive by a larger margin than in the pre-crisis period. Canada and the US have one of the world's most outstanding investment relationships. Many factors, such as strong GDP growth, low tax rates, and a common language, account for the US being the largest foreign investor in Canada.

\section{Conclusion}

As with many other studies that have investigated the determinants of FDI, our empirical work also takes into account the possibility that both the decisionmaking criteria and their importance to decision makers may change over time. The fact is that missing data jeopardizes the validity of FDI theories. In order 
to avoid selection bias, fifteen robust FDI determinants were employed in our model. This study aimed to contribute to the literature by considering the latest robust FDI determinants as decision-making criteria and by investigating investment destination priorities in three different time periods (pre-crisis, crisis, and post-crisis), and by developing a model based on a combination of AHP, TOPSIS, and MP-MADM techniques. This combination of methods has meant that our results are more robust and to the best of our knowledge have not as yet been employed in investigating determinants of FDI.

In addition, it should be pointed out that the process of pairwise comparison relating to criterion weight determination was carried out after the crisis period even though expert judgments were required in order to consider the environmental factors that existed in each period. Specifically, the judgments may differ since they were made during the pre-crisis and crisis periods. Meanwhile, considering the subjective attribution of the AHP method, during this study only four investment experts' opinions were considered, partly due to our limited access to investment experts; however, increasing the number of experts could reinforce the validity of the criterion weights in this methodology. Therefore, based on the above acknowledgements, the following findings were obtained from our analysis.

This model can be used for various sets of countries in different spans of time as well. In addition, it could be considered an important decision-making tool for attaining optimum results. Policymakers and other decision makers can obtain the best priority in increasing FDI outflows to destination countries in different economic situations. Meanwhile, this model can assist policymakers in dealing with different aspects of FDI. This model can also help to improve the investment climate and relations between countries. In addition, investment barriers can be identified and analyzed when using this method.

Further research might use different decision-making approaches such as SAW and ELECTRE, or employ aggregated methodologies such as the Borda and Copeland methods for prioritizing the alternatives. Moreover, window data envelopment analysis (DEA) can be implemented to analyze the priority of alternatives and the efficiency of the decision-making unit during the different periods. The designed framework can be also used in different fields, such as project management, portfolio management, tourism management, and so on.

\section{Acknowledgement}

We would like to thank two anonymous reviewers for their helpful suggestions and comments. 


\section{References}

[1] Abid, F. and Bahloul, S. (2011). Selected MENA countries' attractiveness to G7 investors. Economic Modelling, 28(5), 2197-2207. doi:10.1016/j.econmod.2011.06.013

[2] Baltagi, B. H., Egger, P. and Pfaffermayr, M. (2007). Estimating models of complex FDI: Are there third-country effects? Journal of Econometrics, 140(1), 260-281. doi:10.1016/j.jeconom.2006.09.009.

[3] Baltagi, B. H., Egger, P. and Pfaffermayr, M. (2008). Estimating regional trade agreement effects on FDI in an interdependent world. Journal of Econometrics, 145(1-2), 194-208. doi:10.1016/j.jeconom.2008.05.017.

[4] Beim, G. and Le'vesque, M. (2006). Country selection for new business venturing: A multiple criteria decision analysis. Long Range Planning, 39(3), 265-293. doi:10.1016/j.lrp.2006.06.001.

[5] Bergstrand, J. H. and Egger, P. (2007). A knowledge-and-physical-capital model of international trade flows, foreign direct investment and multinational enterprises. Journal of International Economics, 73(3), 278-308. doi:10.1016/j.jinteco.2007.03.004.

[6] Blonigen, B. A. (2005). A review of the empirical literature on FDI determinants. Atlantic Economics, 33(4), 383-403. doi:10.1007/s11293-005-2868-9.

[7] Blonigen, B. A., Davies, R. B., Waddel, G. R. and Naughton, H. T. (2007). FDI in space: Spatial autoregressive relationships in foreign direct investment. European Economic Review, 51(5), 1303-1325. doi:10.1016/j.euroecorev.2006.08.006.

[8] Chou, C.C. (2009). An integrated quantitative and qualitative FMCDM model for location choices. Soft Computing, 14(7), 757-771. doi:10.1007/s00500-009-0463-8.

[9] Crespo, N. and Fontoura, M. P. (2006). Determinant factors of FDI spillovers What do we really know? Development Economics, 80(2), 444-477.

[10] Eicher, T. S., Helfman, L. and Lenkoski, A. (2012). Robust FDI determinants: Bayesian model averaging in the presence of selection bias. Journal of Macroeconomics, 34(3), 637-651. doi:10.1016/j.jmacro.2012.01.010.

[11] Ekholm, K., Forslid, R., and Markusen, A. R. (2007). Export-platform foreign direct investment. Journal of the European Economic Association, 5(4), 776-795. doi:10.1162/jeea.2007.5.4.776.

[12] Goldberg, L. S. and Kolstad, C. D. (1995). Foreign direct investment, exchange rate variability and demand uncertainty. International Economic Review, 36(4), 855-873. doi: $10.2307 / 2527262$.

[13] Grčić, B. and Babić, Z. (2003). The determinants of FDI: evaluation of transition countries attractiveness for foreign investors. 5th International Conference Enterprise in Transition. Tučepi.

[14] Hwang, C. and Yoon, K. (1981). Multiple attribute decision making. Lecture notes in Economics and Mathematical Systems 186, Springer-Verlag.

[15] Karimi, M. S., Yusop, Z. and Law, S. H. (2010). Location decision for foreign direct investment in ASEAN countries: A TOPSIS approach. International Research Journal of Finance and Economics, 36, 196-207.

[16] Kaya, T. and Kahraman, C. (2011). Multi criteria decision making in energy planning using a modified fuzzy TOPSIS methodology. Expert Systems with Applications, 38(6), 6577-6585. doi:10.1016/j.eswa.2010.11.081. 
[17] Lee, C.C. and Chang, C. P. (2009). FDI, financial development, and economic growth: international evidence. Applied Economics, 12(2), 249-271. doi:10.1016/s1514-0326(09)60015-5.

[18] Levary, R. R. and Wan, K. (1999). An analytic hierarchy process based simulation model for entry mode decision regarding foreign direct investment. Omega, 27(6), 661-677. doi:10.1016/s0305-0483(99)00032-8.

[19] Lin, C. T. and Tsai, M. C. (2009). Development of an expert selection system to choose ideal cities for medical service ventures. Expert Systems with Applications, 36(2), 2266-2274. doi:10.1016/j.eswa.2007.12.056.

[20] Meziani, A. S. (2003). Assessing the effect of investment barriers on international capital flows using an expert-driven system. Multinational Business Review, 11(2), 49-74. doi:10.1108/1525383x200300011.

[21] Moosa, A. (2002). Foreign Direct Investment, Theory, Evidence and Practice. New York: Palgrave.

[22] Mutti, J. and Grubert, H. (2004). Empirical asymmetries in foreign direct investment and taxation. Journal of International Economics, 62(2), 337-358. doi:10.1016/s0022-1996(03)00016-3.

[23] Navaretti, B. G. and Venables, A. J. (2004). Multinational Firms in the World Economy. New Jersy: Princeton University Press.

[24] OECD (2008). The OECD benchmark definition. Retrieved from OECD benchmark definition of foreign direct investment: http://www.oecd.org/ [Accessed on 15 September 2015].

[25] Oh, C. H., Selmier, W. and Lien, D. (2011). International trade, foreign direct investment, and transaction costs in languages. The Journal of Socio-Economics, 40(6), 732-735. doi:10.1016/j.socec.2011.08.003.

[26] Radfar, R. and Ebrahimi, L. (2012). Fuzzy multi criteria decision making model for prioritizing the investment methods in technology transfer in shipping industries. International Conference on Industrial Engineering and Operations Management. Istanbul, Turkey.

[27] Razin, A. and Sadka, E. (2007). Foreign Direct Investment: Analysis of Aggregate Flows. Princeton University Press.

[28] Razin, A., Sadka, E., and Tong, H. (2008). Bilateral FDI flows: Threshold barriers and productivity shocks. CESifo Economic Studies, 54(3), 451-470. doi:10.1093/cesifo/ifn025.

[29] Saaty, T. L. (1977). A scaling method for priorities in hierarchical structures. Journal of Mathematical Psychology, 15(3), 234-281. doi:10.1016/00222496(77)90033-5.

[30] Saaty, R. (1987). The analytic hierarchy process-what it is and how it is used. Mathematical Modelling, 9(3-5), 161-176. doi:10.1016/0270-0255(87)90473-8.

[31] Saraoglu, H. and Detzler, M. L. (2002). A sensible mutual fund selection model. Financial Analysts Journal, 58(3), 60-72. doi:10.2469/faj.v58.n3.2538.

[32] Wagner, H. M. (1975). Principles of Operation Research with Application to Managerial Decisions. New Jersey: Prentice-Hall, Inc., Englewood Cliffs.

[33] Xiajing, D. and Junjie, Z. (2011). The TOPSIS analysis on regional disparity of economic development in zhejiang province. Canadian Social Science, 7(5), 135-139. 
[34] Yang, T., Chen, M.C. and Hung, C.C. (2007). Multiple attribute decision-making methods for the dynamic operator allocation problem. Mathematics and Computers in Simulation, 73(5), 285-299. doi:10.1016/j.matcom.2006.04.002.

[35] Zhao, C. and Du, J. (2007). Causality between FDI and economic growth in China. Chinese Economy, 40(6), 68-82. doi:10.2753/ces1097-1475400604.

\section{APPENDIX:}

Table A-1: Saaty Rating Scale

\begin{tabular}{|c|c|c|}
\hline $\begin{array}{l}\text { Intensity of } \\
\text { importance }\end{array}$ & Definition & Explanation \\
\hline 1 & $\begin{array}{l}\text { Equal importance of both } \\
\text { elements }\end{array}$ & Two factors contribute equally to the objective \\
\hline 3 & $\begin{array}{l}\text { Weak importance of one } \\
\text { element over another }\end{array}$ & $\begin{array}{l}\text { Experience and judgement slightly favour one over the } \\
\text { other }\end{array}$ \\
\hline 5 & $\begin{array}{l}\text { Essential or strong importance of } \\
\text { one element over another }\end{array}$ & $\begin{array}{l}\text { Experience and judgement strongly favour one over the } \\
\text { other }\end{array}$ \\
\hline 7 & $\begin{array}{l}\text { Demonstrated importance of one } \\
\text { element over another }\end{array}$ & $\begin{array}{l}\text { Experience and judgement very strongly favour one over } \\
\text { the other. Its importance is demonstrated in practice }\end{array}$ \\
\hline 9 & $\begin{array}{l}\text { Absolute importance of one } \\
\text { element over another }\end{array}$ & $\begin{array}{l}\text { The evidence favouring one over the other is of the } \\
\text { highest possible validity }\end{array}$ \\
\hline $2,4,6,8$ & $\begin{array}{l}\text { Intermediate values between } \\
\text { two adjacent judgments }\end{array}$ & When compromise is needed \\
\hline $\begin{array}{l}\text { Reciprocals of } \\
\text { the above non- } \\
\text { zero numbers }\end{array}$ & $\begin{array}{l}\text { If activity } i \text { has one of the above non-zero numbers } \\
\text { assigned to it when compared with activity j, then } j \\
\text { has the reciprocal value when compared to } i\end{array}$ & \\
\hline
\end{tabular}

Table A-2: Saaty Consistency Index Table

\begin{tabular}{|llllllllllllllll|}
\hline $\mathrm{n}$ & 1 & 2 & 3 & 4 & 5 & 6 & 7 & 8 & 9 & 10 & 11 & 12 & 13 & 14 & 15 \\
\hline IRI & 0.00 & 0.00 & 0.58 & 0.90 & 1.12 & 1.24 & 1.32 & 1.41 & 1.45 & 1.49 & 1.51 & 1.48 & 1.56 & 1.57 & 1.59 \\
\hline
\end{tabular}

Table A-3: Aggregated Decision Matrix (Pre Crisis)

\begin{tabular}{|c|c|c|c|c|c|c|c|c|c|c|c|c|c|c|c|}
\hline & DISTANC: & MRKT SIZE & COLONY & COM LANG & $\begin{array}{l}\text { DEVELOPM } \\
\mathrm{T}\end{array}$ & $\begin{array}{l}N \text { GDP } \\
\text { GROWTH }\end{array}$ & $\begin{array}{l}\text { MRKT } \\
\text { POTENTIAL }\end{array}$ & $\begin{array}{l}\text { PRODUCTIV } \\
\text { TTY }\end{array}$ & TAX & LAIA & APEC & DOLLAR & CORRUPT & $\begin{array}{l}\text { INTERN } \\
\text { CONFLCT }\end{array}$ & $\begin{array}{l}\text { RELIGIOUS } \\
\text { TENSION }\end{array}$ \\
\hline United Kingdom & 0.0121 & 0.0466 & 0.0093 & 0.0071 & 0.0256 & 0.0311 & 0.0455 & 0.0395 & 0.0152 & 0.0078 & 0.0064 & 0.0049 & 0.0124 & 0.0126 & 0.0224 \\
\hline Netherland & 0.0127 & 0.0135 & 0.0047 & 0.0035 & 0.0274 & 0.0284 & 0.0735 & 0.0408 & 0.0205 & 0.0078 & 0.0064 & 0.0049 & 0.0139 & 0.0206 & 0.0119 \\
\hline Canada & 0.0012 & 0.0266 & 0.0047 & 0.0071 & 0.0272 & 0.0336 & 0.0107 & 0.0389 & 0.0205 & 0.0078 & 0.0127 & 0.0099 & 0.0132 & 0.0189 & 0.0224 \\
\hline Luxembourg & 0.0131 & 0.0007 & 0.0047 & 0.0035 & 0.0531 & 0.0543 & 0.0741 & 0.0932 & 0.0089 & 0.0078 & 0.0064 & 0.0049 & 0.0139 & 0.0197 & 0.0224 \\
\hline Ireland & 0.0111 & 0.0038 & 0.0047 & 0.0071 & 0.0301 & 0.0583 & 0.0373 & 0.0482 & 0.0111 & 0.0078 & 0.0064 & 0.0049 & 0.0096 & 0.0189 & 0.0187 \\
\hline Switzerland & 0.0136 & 0.0065 & 0.0047 & 0.0035 & 0.0289 & 0.0328 & 0.0500 & 0.0402 & 0.0125 & 0.0078 & 0.0064 & 0.0049 & 0.0126 & 0.0193 & 0.0187 \\
\hline Germany & 0.0131 & 0.0608 & 0.0047 & 0.0035 & 0.0244 & 0.0201 & 0.0485 & 0.0383 & 0.0209 & 0.0078 & 0.0064 & 0.0049 & 0.0131 & 0.0175 & 0.0224 \\
\hline Australia & 0.0347 & 0.0156 & 0.0047 & 0.0071 & 0.0253 & 0.0391 & 0.0074 & 0.0384 & 0.0227 & 0.0078 & 0.0127 & 0.0049 & 0.0132 & 0.0174 & 0.0224 \\
\hline Japan & 0.0235 & 0.0914 & 0.0047 & 0.0035 & 0.0237 & 0.0202 & 0.0146 & 0.0357 & 0.0230 & 0.0078 & 0.0127 & 0.0049 & 0.0098 & 0.0158 & 0.0205 \\
\hline
\end{tabular}


Table A-4: Aggregated Decision Matrix (Crisis)

\begin{tabular}{|c|c|c|c|c|c|c|c|c|c|c|c|c|c|c|c|}
\hline & DISTANCE & MRKT SIZE & COLONY & COM LANG & $\begin{array}{l}\text { DEVELOPM } \\
\text { ENT }\end{array}$ & $\begin{array}{l}\text { GDP } \\
\text { GROWTH }\end{array}$ & $\begin{array}{l}\text { MRKT } \\
\text { POTENTIAL }\end{array}$ & $\begin{array}{l}\text { PRODUCTIV } \\
\text { ITY }\end{array}$ & $\operatorname{TAX}$ & LAIA & APEC & DOLLAR & CORRUPT & $\begin{array}{l}\text { INTERN } \\
\text { CONFLLCT }\end{array}$ & 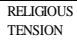 \\
\hline United Kingdom & 0.0123 & 0.0482 & 0.0080 & 0.0061 & 0.0225 & -0.0104 & 0.0412 & 0.0326 & 0.0148 & 0.0060 & 0.0049 & 0.0036 & 0.0166 & 0.0134 & 0.0242 \\
\hline Netherland & 0.0130 & 0.0143 & 0.0040 & 0.0030 & 0.0250 & 0.0172 & 0.0659 & 0.0341 & 0.0170 & 0.0060 & 0.0049 & 0.0036 & 0.0208 & 0.0238 & 0.0113 \\
\hline Canada & 0.0012 & 0.0276 & 0.0040 & 0.0061 & 0.0238 & 0.0037 & 0.0101 & 0.0316 & 0.0187 & 0.0060 & 0.0098 & 0.0072 & 0.0208 & 0.0218 & 0.0242 \\
\hline Luxembourg & 0.0134 & 0.0008 & 0.0040 & 0.0030 & 0.0477 & 0.0034 & 0.0665 & 0.0772 & 0.0086 & 0.0060 & 0.0049 & 0.0036 & 0.0208 & 0.0222 & 0.0242 \\
\hline Ireland & 0.0113 & 0.0040 & 0.0040 & 0.0061 & 0.0263 & -0.0195 & 0.0339 & 0.0395 & 0.0109 & 0.0060 & 0.0049 & 0.0036 & 0.0146 & 0.0227 & 0.0202 \\
\hline Switzerland & 0.0139 & 0.0070 & 0.0040 & 0.0030 & 0.0261 & 0.0274 & 0.0452 & 0.0336 & 0.0121 & 0.0060 & 0.0049 & 0.0036 & 0.0187 & 0.0215 & 0.0184 \\
\hline Germany & 0.0134 & 0.0634 & 0.0040 & 0.0030 & 0.0222 & 0.0019 & 0.0441 & 0.0320 & 0.0204 & 0.0060 & 0.0049 & 0.0036 & 0.0208 & 0.0208 & 0.0215 \\
\hline Australia & 0.0355 & 0.0171 & 0.0040 & 0.0061 & 0.0229 & 0.0566 & 0.0071 & 0.0320 & 0.0211 & 0.0060 & 0.0098 & 0.0036 & 0.0187 & 0.0191 & 0.0242 \\
\hline Japan & 0.0241 & 0.0918 & 0.0040 & 0.0030 & 0.0206 & -0.0235 & 0.0149 & 0.0292 & 0.0233 & 0.0060 & 0.0098 & 0.0036 & 0.0125 & 0.0187 & 0.0222 \\
\hline
\end{tabular}

Table A- 5: Aggregated Decision Matrix (Post Crisis)

\begin{tabular}{|llllllllllllllllll|}
\hline & DISTANCE & MRKT SIZE & COLONY & \multicolumn{2}{c|}{ COM LANG } & $\begin{array}{l}\text { DEVELOPM } \\
\text { ENT }\end{array}$ & $\begin{array}{l}\text { GDP } \\
\text { GROWTH }\end{array}$ & $\begin{array}{l}\text { MRKT } \\
\text { POTENTIAL }\end{array}$ ITY & PRODCTIV & TAX & LAIA & APEC & DOLAR & CORRUPT & $\begin{array}{l}\text { INTERN } \\
\text { CONFLICT }\end{array}$ & $\begin{array}{l}\text { RELIGIOUS } \\
\text { TENSION }\end{array}$ \\
\hline United Kingdom & 0.0175 & 0.0495 & 0.0076 & 0.0057 & 0.0341 & 0.0172 & 0.0358 & 0.0286 & 0.0159 & 0.0070 & 0.0057 & 0.0043 & 0.0139 & 0.0169 & 0.0222 \\
Netherland & 0.0185 & 0.0148 & 0.0038 & 0.0029 & 0.0383 & 0.0060 & 0.0571 & 0.0307 & 0.0175 & 0.0070 & 0.0057 & 0.0043 & 0.0169 & 0.0233 & 0.0148 \\
Canada & 0.0017 & 0.0295 & 0.0038 & 0.0057 & 0.0370 & 0.0463 & 0.0091 & 0.0285 & 0.0116 & 0.0070 & 0.0114 & 0.0086 & 0.0169 & 0.0214 & 0.0222 \\
Luxembourg & 0.0191 & 0.0008 & 0.0038 & 0.0029 & 0.0705 & 0.0271 & 0.0575 & 0.0646 & 0.0088 & 0.0070 & 0.0057 & 0.0043 & 0.0169 & 0.0204 & 0.0222 \\
Ireland & 0.0161 & 0.0040 & 0.0038 & 0.0057 & 0.0381 & 0.0144 & 0.0295 & 0.0344 & 0.0113 & 0.0070 & 0.0057 & 0.0043 & 0.0122 & 0.0224 & 0.0185 \\
Switzerland & 0.0197 & 0.0075 & 0.0038 & 0.0029 & 0.0408 & 0.0350 & 0.0391 & 0.0304 & 0.0128 & 0.0070 & 0.0057 & 0.0043 & 0.0156 & 0.0204 & 0.0167 \\
Germany & 0.0190 & 0.0674 & 0.0038 & 0.0029 & 0.0356 & 0.0452 & 0.0381 & 0.0295 & 0.0205 & 0.0070 & 0.0057 & 0.0043 & 0.0169 & 0.0204 & 0.0185 \\
Australia & 0.0504 & 0.0189 & 0.0038 & 0.0057 & 0.0365 & 0.0549 & 0.0066 & 0.0295 & 0.0210 & 0.0070 & 0.0114 & 0.0043 & 0.0164 & 0.0205 & 0.0222 \\
Japan & 0.0342 & 0.0953 & 0.0038 & 0.0029 & 0.0323 & 0.0332 & 0.0147 & 0.0264 & 0.0215 & 0.0070 & 0.0114 & 0.0043 & 0.0149 & 0.0177 & 0.0204 \\
\hline
\end{tabular}

